WINTERS, Steven L, Earth and Environmental Science, Holyoke Community College, 303 Homestead Ave., Holyoke, MA ono40,

TROBAUGH, Elizabeth, English Department, Holyoke Community College, 303 Homestead Ave., Holyoke, MA 011040,

\title{
CLI-FI AT 2Y: LEARNING GEOSCIENCE THROUGH CLIMATE-CHANGE FICTION
}




\section{It's weird how the power of wonder works.}

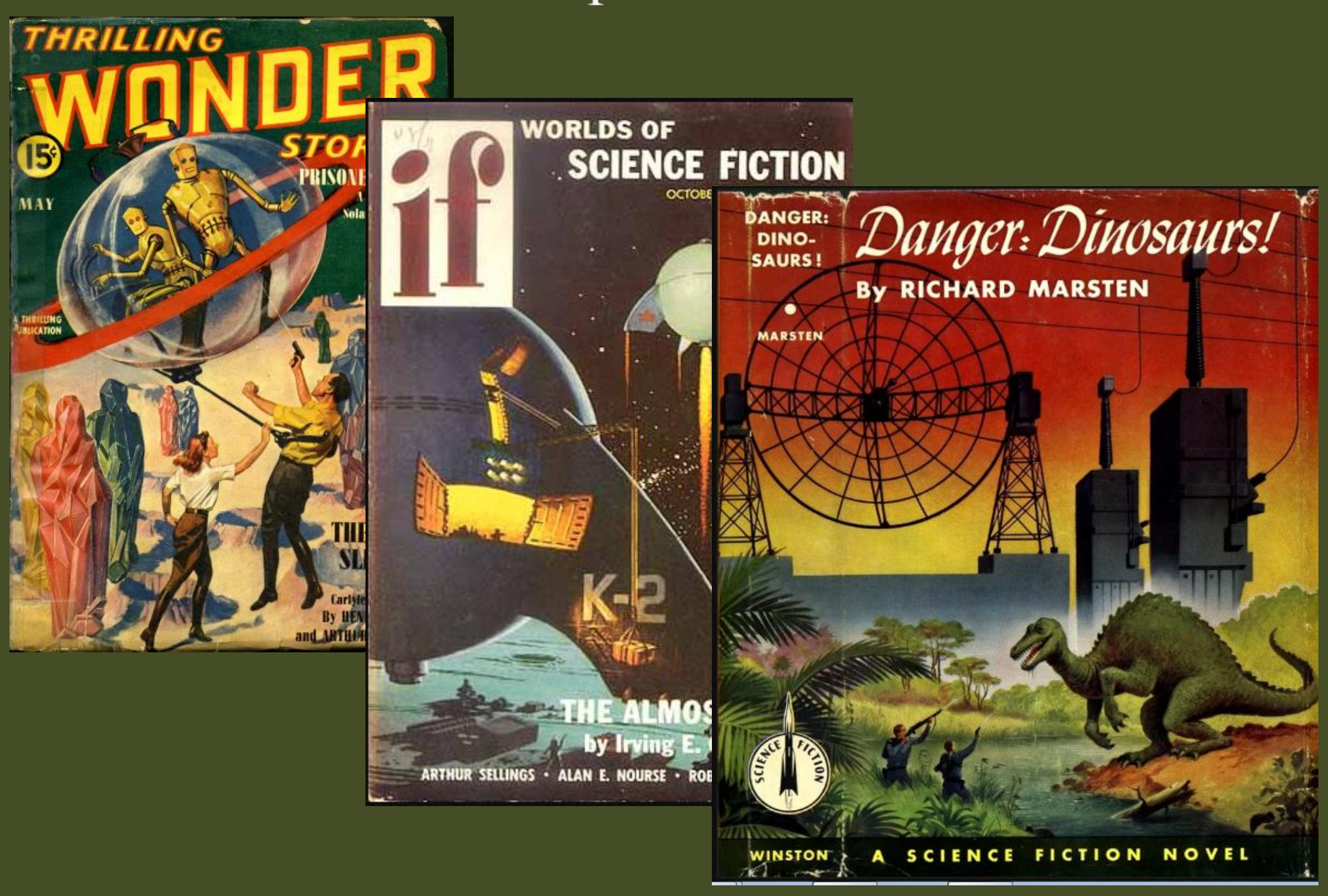




\section{It's weird how the power of wonder works.}

- How can science fiction - sometimes outlandish engage the science geek in us? One word: wonder.

- Can geo-educators - 2y and $4 \mathrm{y}-\mathrm{use}$ SF/sci-fi in the classroom?

- Can climate-change fiction - i.e., "cli-fi" - change the planet? Articles from these sources suggest yes.

- The Atlantic

- NRDC

- Reuters/The New York Times 
https://www.theatlantic.com/entertainment/archive/2015/08 /climate-fiction-margaret-atwood-literature/400112/

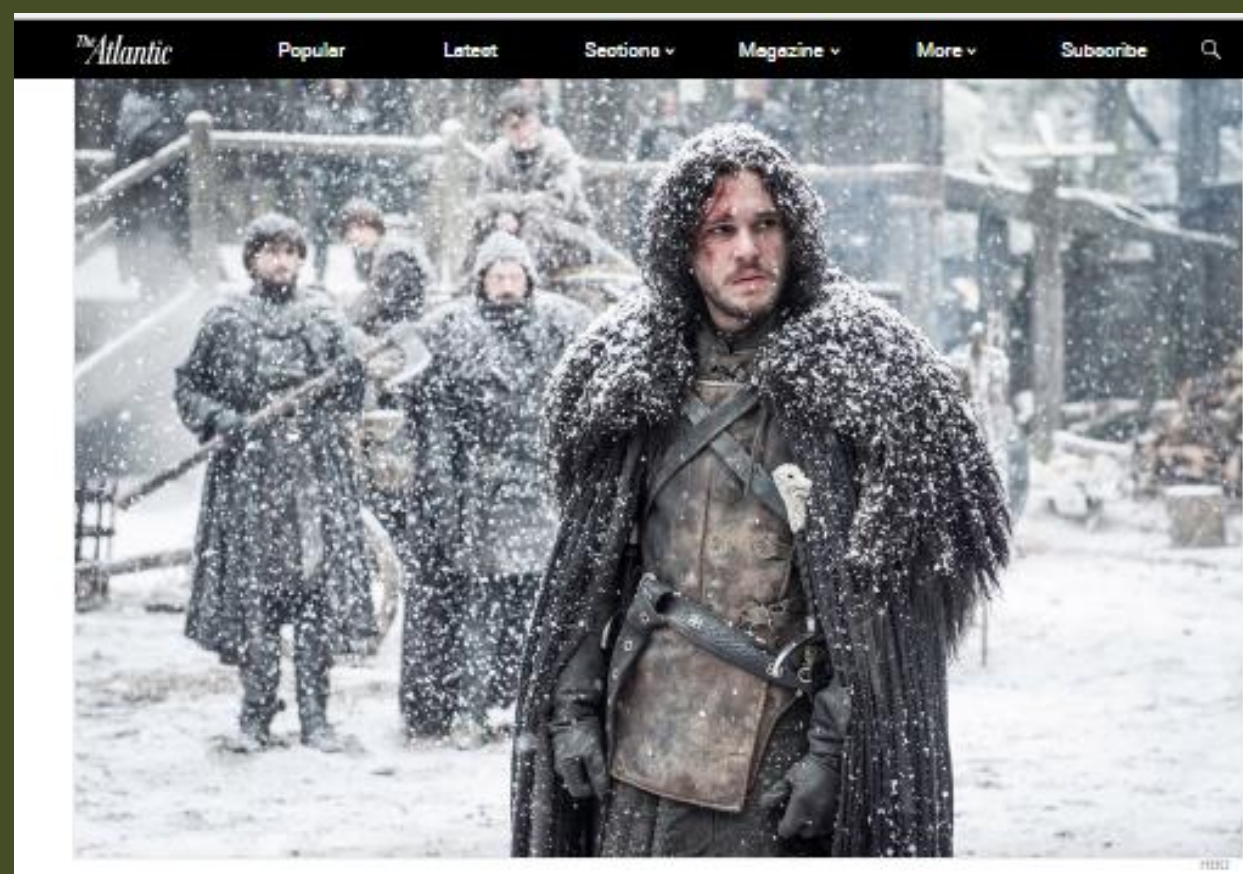

\section{Climate Fiction: Can} Books Save the Planet?

A new iterary genre that focuses on the consequences of environmenta Asues is striking a choro with younger generations-and engaging them In thinking about the Earth's sustainability.

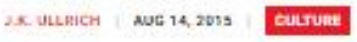

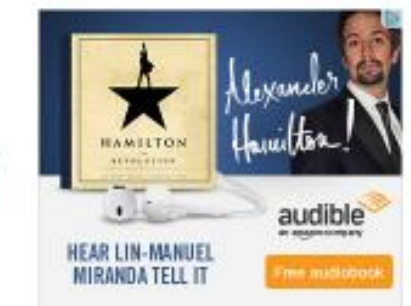

ff share 1 tweet 


\section{https://www.nrdc.org/onearth/apocalyp}

\section{sesoon}

Review of Claire Vaye Watkins' novel, Gold Fame Citrus.

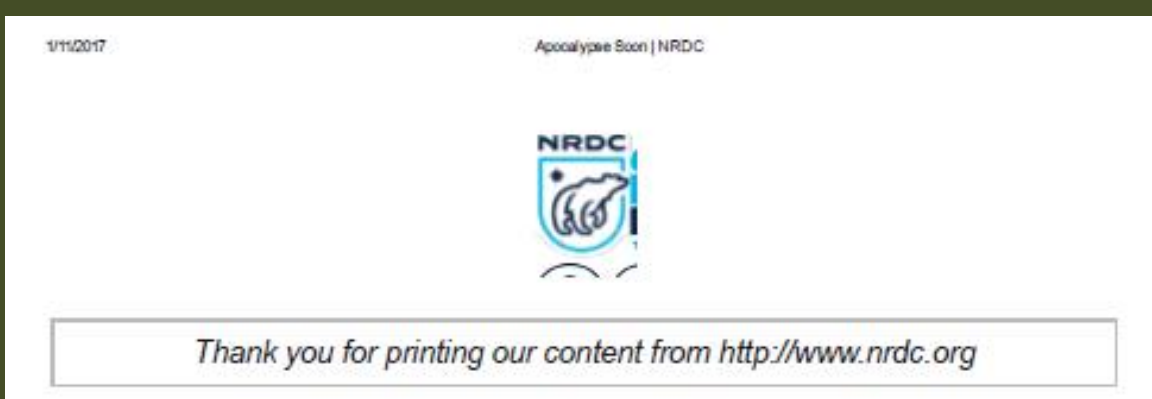

\section{Apocalypse Soon}

In the budding cli-fi genre, dystopian settings can be real-life motivators.

February 04,2016

Lell Turrentine

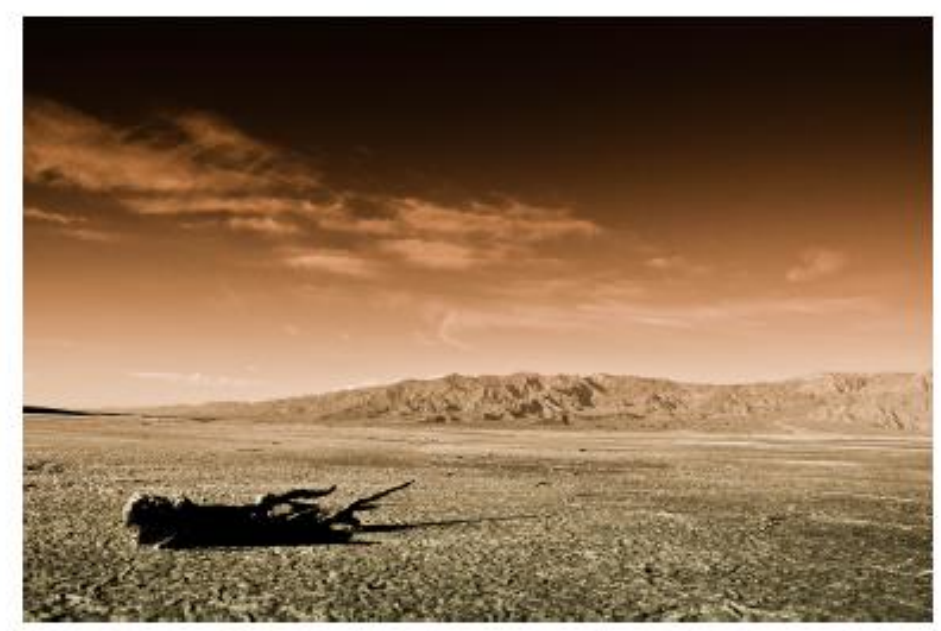




\section{REUTERS \\ Business \\ Markets \\ World \\ Politics \\ Tech \\ Commentary \\ Breakingviews \\ Move over sci-fi: 'Climate fiction' finds way into classrooms}

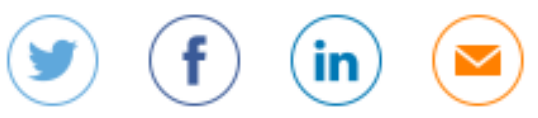

By Kyle Plantz

LONDON (Thomson Reuters Foundation) - Students at a Massachusetts college have just read "The Windup Girl", the tale of a dystopian future Bangkok where climate change has pushed up temperatures and sea levels, and viruses acquired from genetically modified food are killing people.

The book, by debut novelist Paolo Bacigalupi, is the product of a new class at Holyoke Community College on "climate fiction" or "cli-fi", a relatively new variant of science fiction.

Around the world, from the United States to Britain to India, cli-fi classes are creeping into timetables as academics try to bring a growing international concern into the classroom in a lively way that combines science and emotion. 


\section{Outline/Objectives}

- Our 2y college - Holyoke Community College (HCC)

- Our course structure

-What is cli-fi? / Cli-fi from "sci-fi"

- Our materials and methods 


\section{Our 2y college - Holyoke CC, MA}

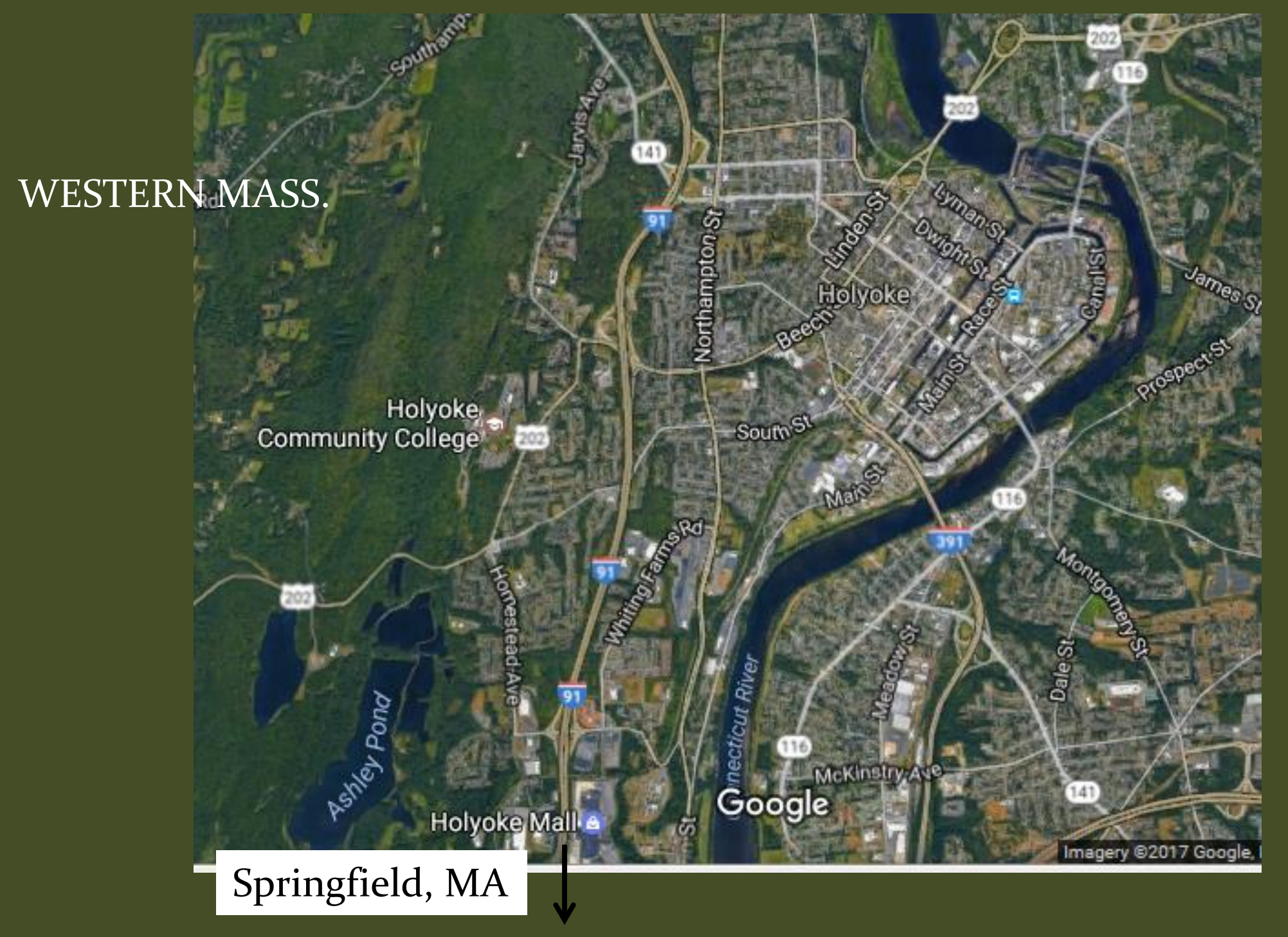




\section{From our website (http://www.hcc.edu/)}

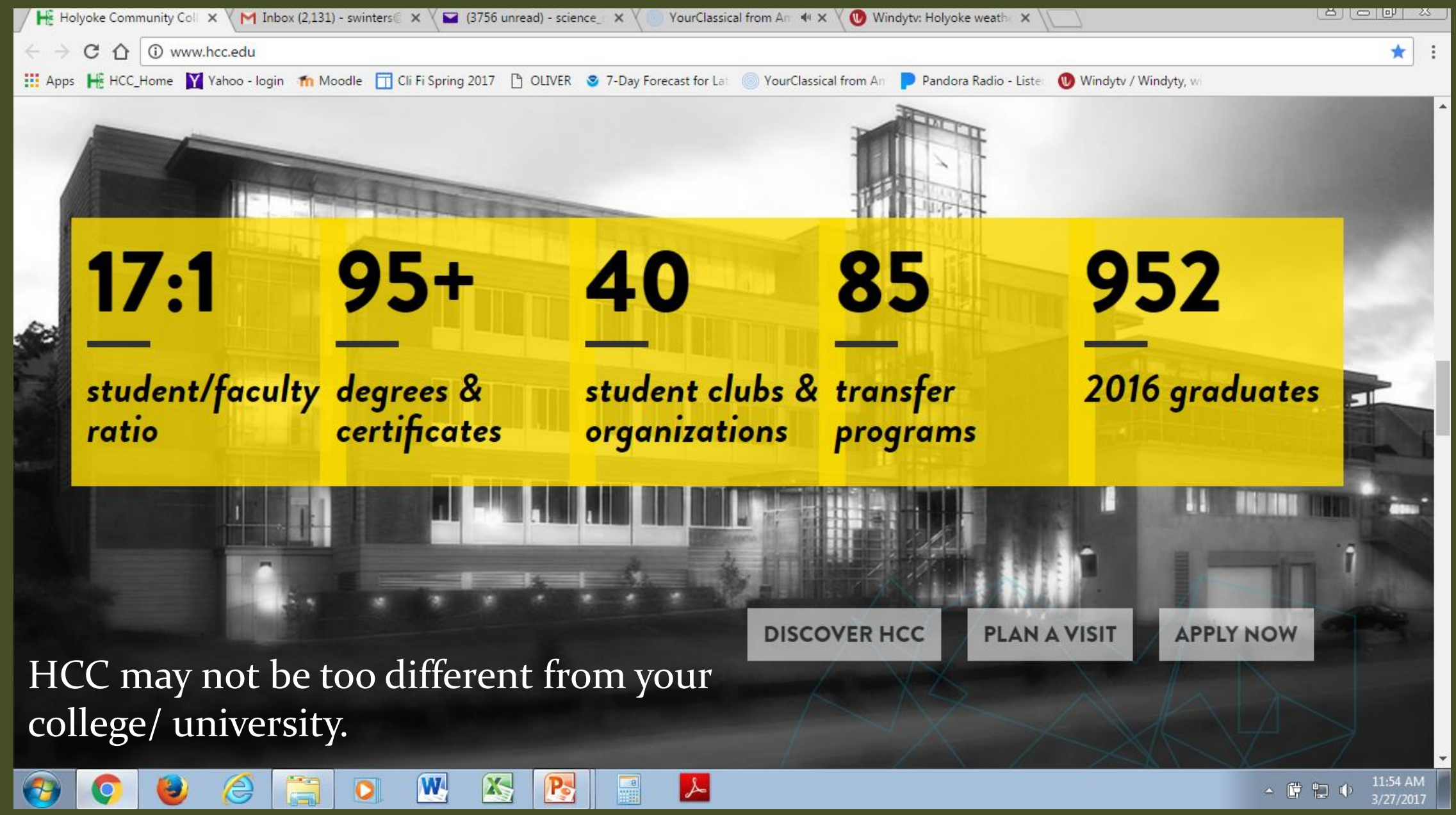




\section{Our course structure - an HCC Learning Community}

- Combines introductory English literature and composition with first-year physical geology (including laboratory and field exercises)

- Field trips include visits to a local natural history museum, rock and fossil sites, including Holyoke earlyJurassic-age dinosaur trackways.

- Interdisciplinary/thematic content, seminar-style discussion and small classes (10-20)

- We call this kind of interdisciplinary/thematic/ collaborative learning at HCC a Learning Community. We are very lucky to have them! 


\section{What is "cli-fi"?}

- A term used to describe anthropogenic climate-change fiction, a sub-genre of science fiction, modelled after the assonance of "sci-fi."

- As Claire Vaye Watkins says, cli-fi brings the imagination to problem-solving equation.

- Some popular novels include,

- The Year of the Flood (Margaret Atwood)

- Science in the Capital Trilogy and (just out) New York 2140 (Kim Stanley Robinson)

- The Windup Girl and The Water Knife (Paolo Bacigalupi)

- $\mathrm{Cl}-\mathrm{fi}$ is best represented by short fiction. Some anthologies we've used,

- I'm With the Bears (edited by Mark Martin, Verso)

- Drowned Worlds (edited by Jonathan Strahan, Solaris)

- Loosed Upon the World (edited by John Joseph Adams, Saga) 


\section{I'm With the Bears (edited by Mark Martin, Verso)}

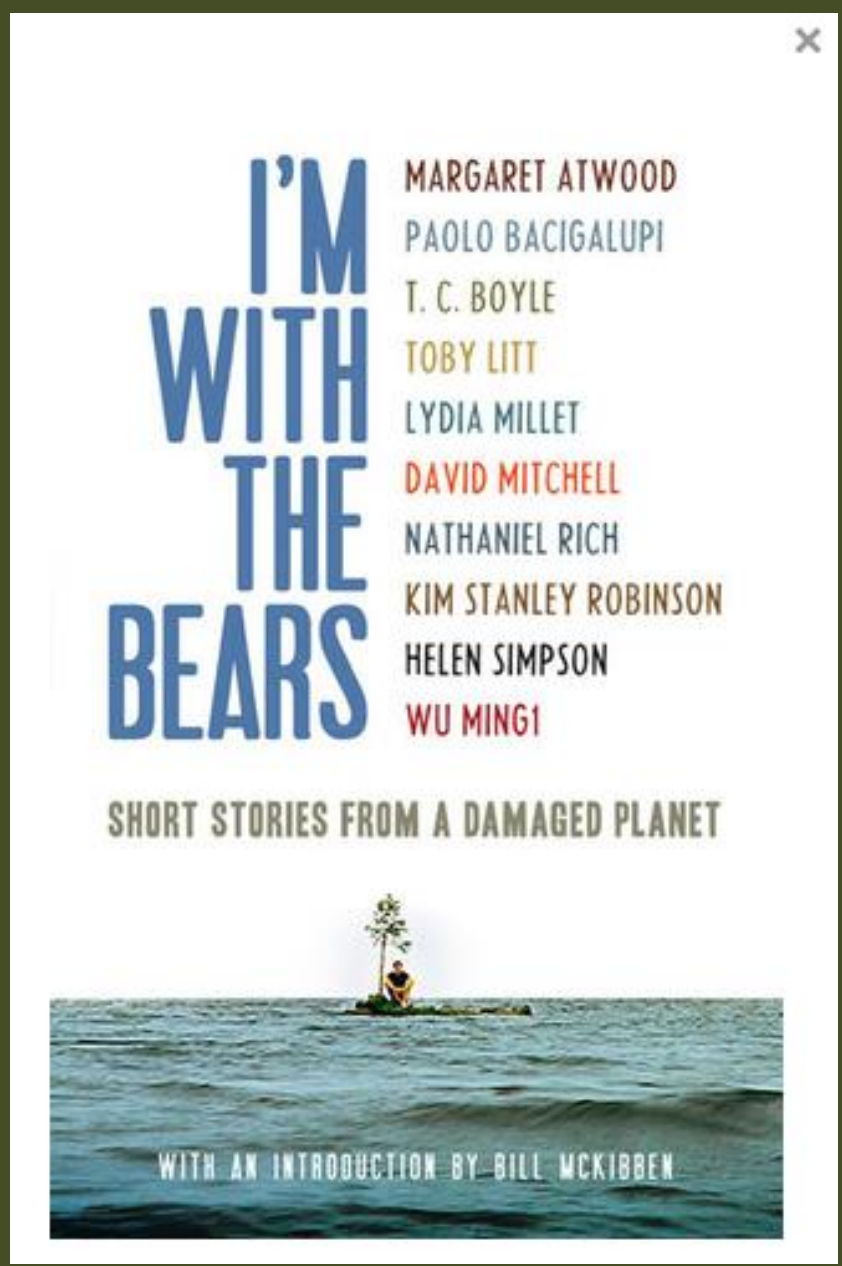




\section{Drowned Worlds (edited by Jonathan Strahan, Solaris)}

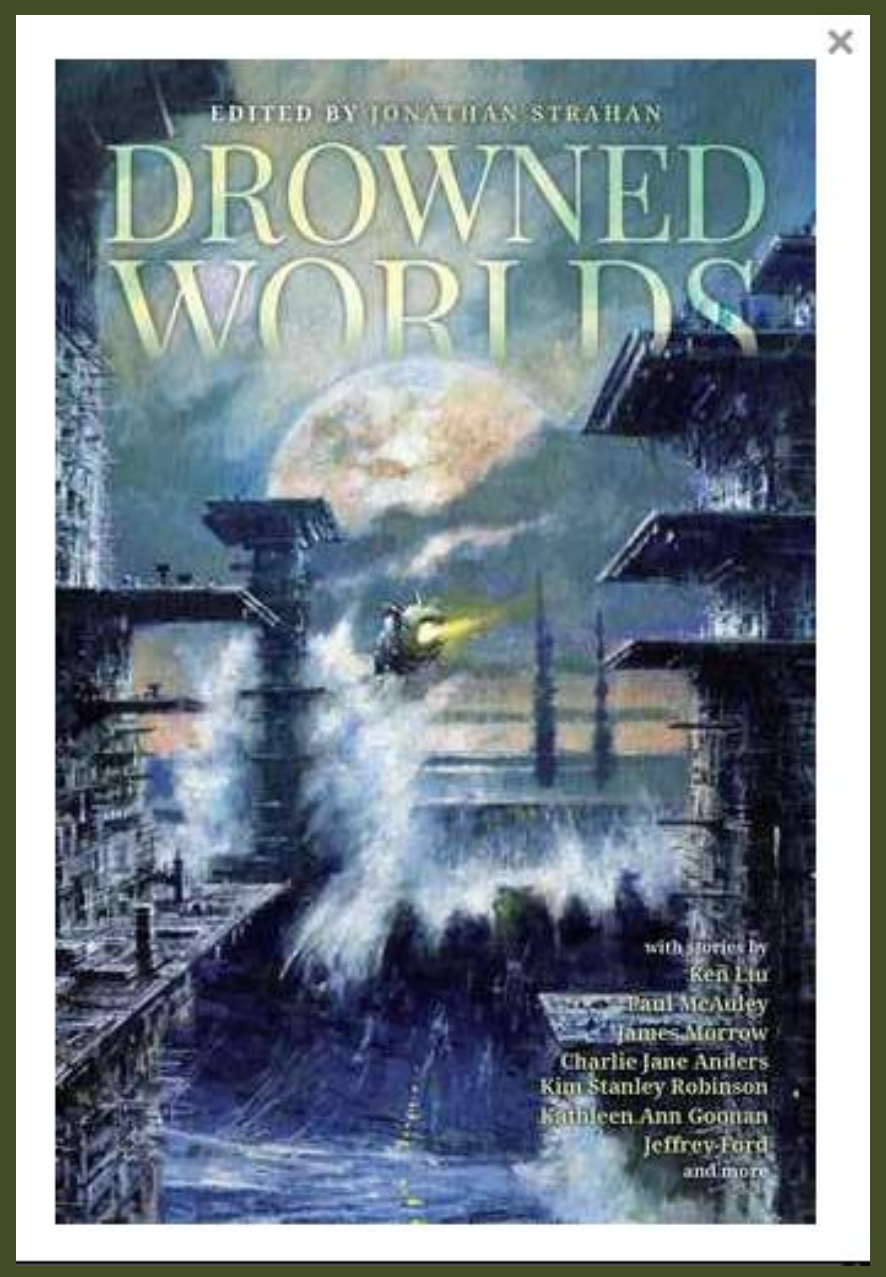




\section{Loosed Upon the World (edited by John Joseph Adams, Saga)}

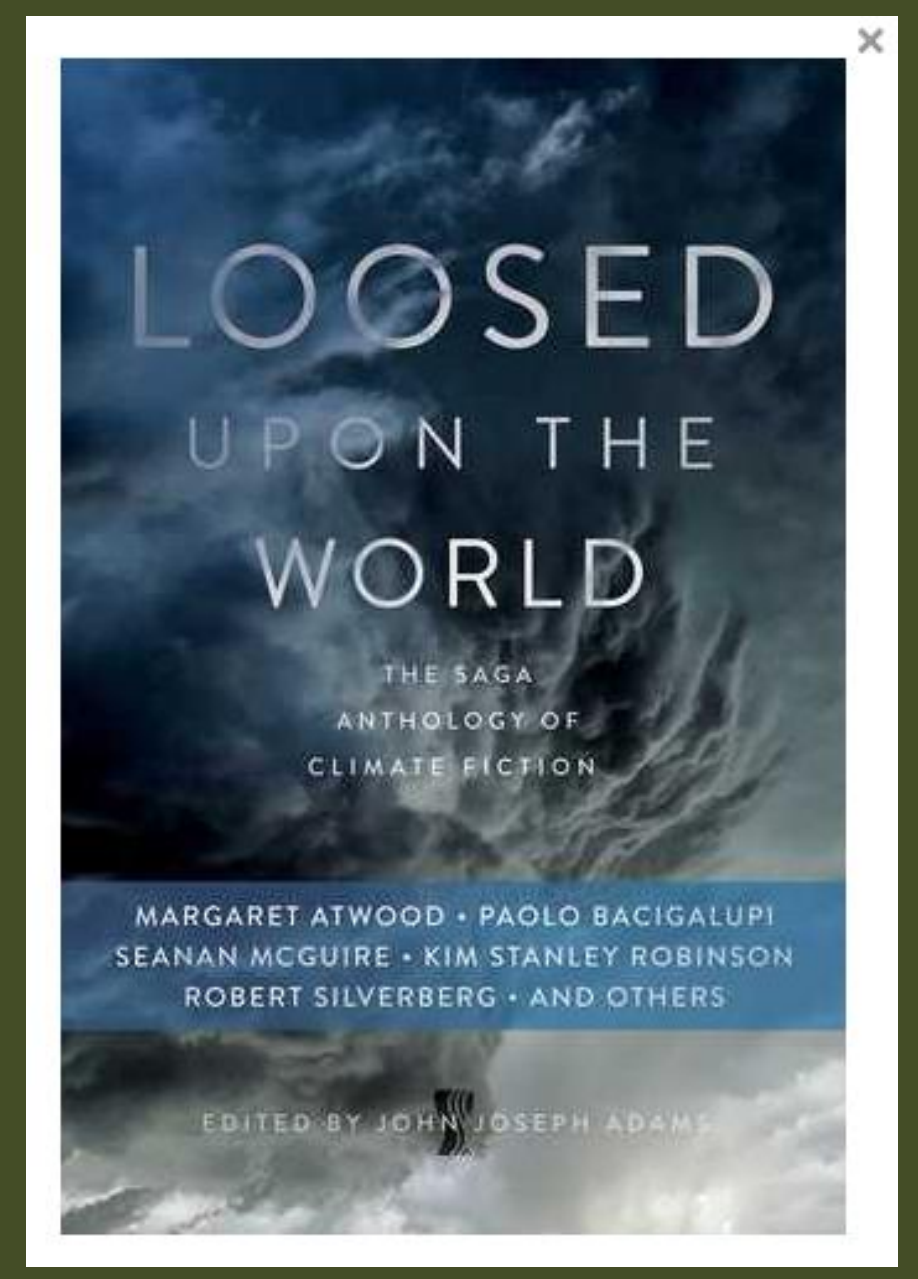




\section{It all begins with a story ...}

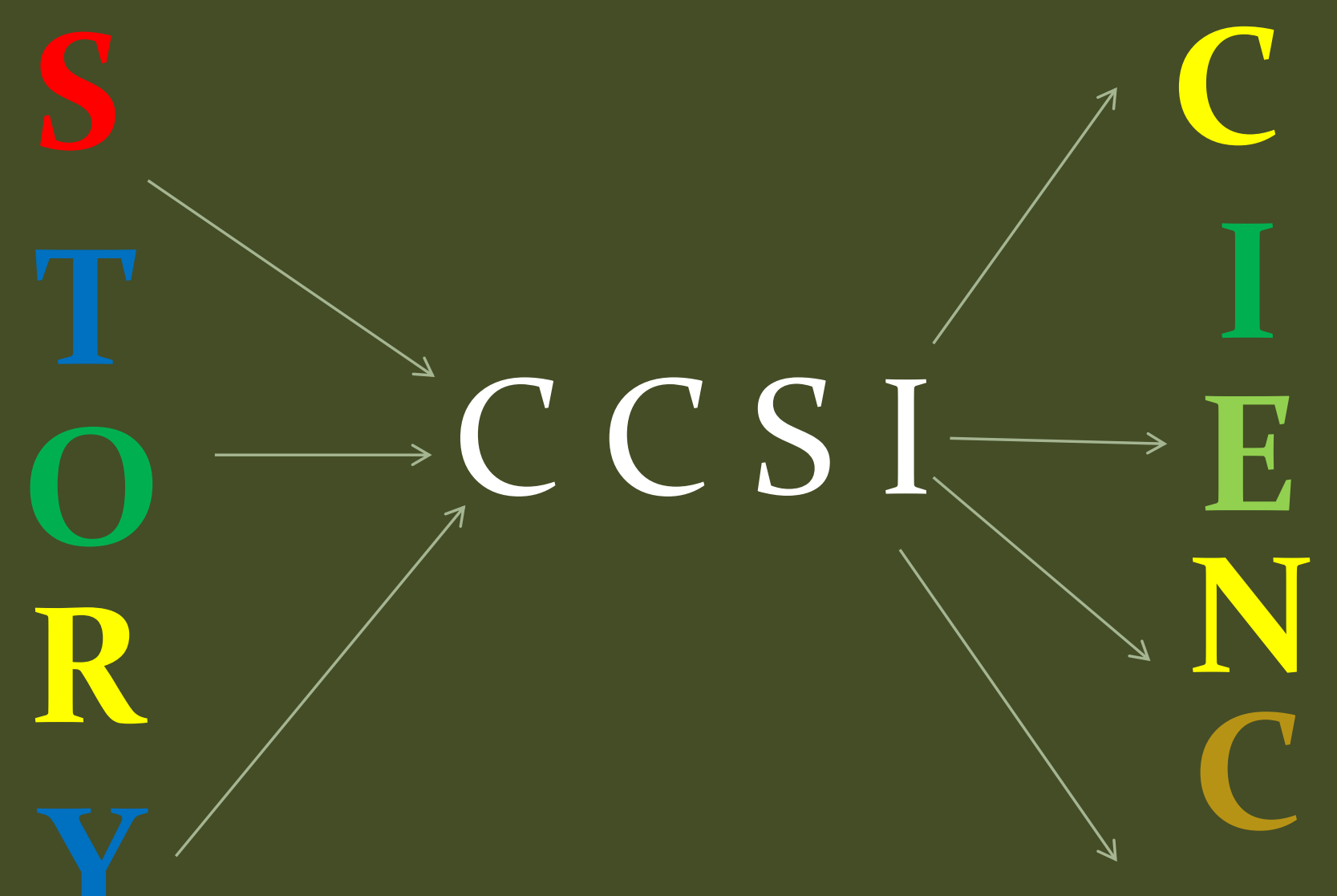




\section{Climate-Change Stress Index (CCSI)}

- For our course, we have developed a tool we call the CCSI to help students identify the evidence of climate-change impacts in the fictional setting of each story.

$\square$ Adaptation/mitigation

$\square$ Breakdown in infrastructure

$\square$ Breakdown in civilization/social order

$\square$ Climate imbalance/disorder

$\square$ Ecosystem imbalance - flora and fauna

$\square$ Illness/disease

$\square$ Positive/negative feedbacks

$\square$ Regression (psychosocial, biological, technological, etc.)

$\square$ Resource scarcity

- The CCSI acts as a window through which students can get an integrated and in-depth view of fiction and science in one lesson. 


\section{Excerpt from "Dispatches from The Cradle" by Ken Liu (in Flooded)}

The legendary island of Singapore is no more. But the idea of Singapore lives on.

The floating family habitats connect to each other in tight clan-strands that weave together into a massive raft-city. From above, the city looks like an algal mat composed of metal and plastic, studded with glistening pearls, dewdrops or air bubbles - the transparent domes and solar collectors for the habitat (39). 


\section{An example CCSI, filled in by our students}

LC 202

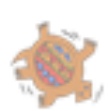

Climase Change Srezs Iodex

For "Dirpastases from the Gadelen"

Instructiom: Please contribste coe factor ( 0 example and a brief quote with page $\Rightarrow$ ) to this shared docvement. Write directy into this shared docvement.

Fond passages that ibusrast the following themes and fercxes of the climate-changed world:

\begin{tabular}{|c|c|c|}
\hline Stress factor impact & $\begin{array}{l}\text { Example from the text - record a brief } \\
\text { quote, with page t, and bullet point } \\
\text { observation(s). }\end{array}$ & $\begin{array}{l}\text { Contributor } \\
\text { (put your } \\
\text { name bere) }\end{array}$ \\
\hline \multicolumn{3}{|l|}{ Breakdomen in infrastrocture } \\
\hline \multirow{2}{*}{$\begin{array}{l}\text { Brealudomen in } \\
\text { civilization isocial order }\end{array}$} & 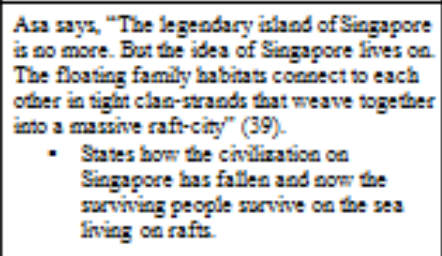 & IC \\
\hline & 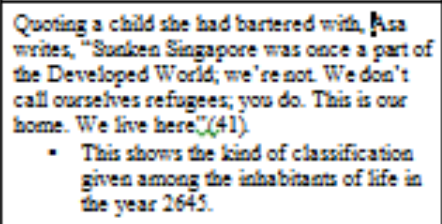 & FB \\
\hline Climate imbalases divorder & 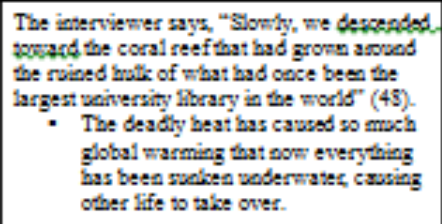 & KS \\
\hline $\begin{array}{l}\text { Econyntem imbalasee-flora } \\
\text { and favea }\end{array}$ & 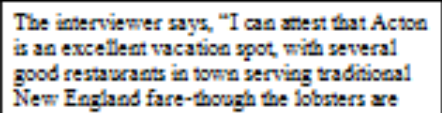 & AA \\
\hline
\end{tabular}

LC 2002

\begin{tabular}{|c|c|c|}
\hline & 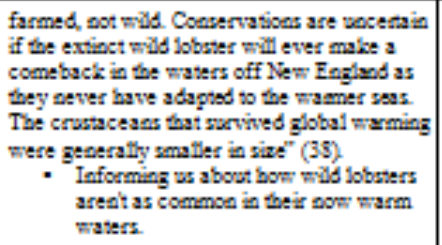 & \\
\hline \multicolumn{3}{|l|}{ Revouce vearcity } \\
\hline \multicolumn{3}{|l|}{$\begin{array}{l}\text { Regression (social } \\
\text { techoological ets.) }\end{array}$} \\
\hline \multicolumn{3}{|l|}{ Illoess } \\
\hline \multirow[b]{2}{*}{ Adaptation } & 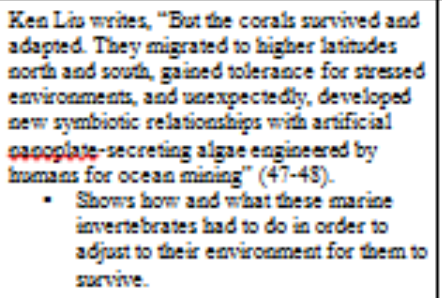 & IC \\
\hline & 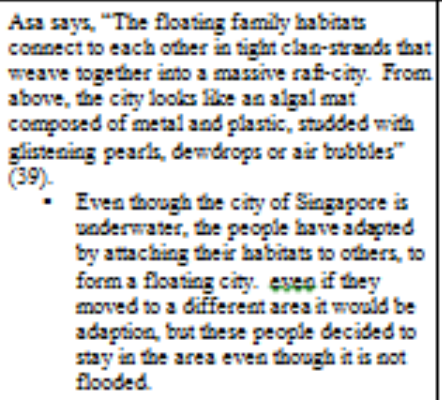 & AM \\
\hline Mrigation & & \\
\hline
\end{tabular}




\section{Story-science "intersects"}

- The CCSI provides the platform for story-science intersects that we initiate and model for students.

- Opportunity to "dig" into a text, discover/explore the science that underlies the narrative

- Used for classroom discussion.

- Intersects also provide a model for student's final cli-fi science project.

- Intersects are fact-finding/fact-checking activities:

- What is the science, if any, that underlies the fiction?

- Is the science used in a believable way?

- Does the story seem plausible?

- Does the story have verisimilitude? 


\section{Intersect example from "Dispatches from The Cradle":}

Text: "... The floating family habitats connect to each other in tight clan-strands that weave together into a massive raft-city. From above, the city looks like an algal mat ..."

Example questions:

- What's an algal mat? What are some examples from the geologic record? From today?

- How did algal mats evolve? What niches were they exploiting and to what advantage (or adaptation) to the organisms that made them?

- How are the algal mats of the Proterozoic Eon similar to/different from the floating habitats of Liu's fictional Singapore? 


\section{http://windupstories.com/books/pump-six-and- other-stories/people-of-sand-and-slag/}

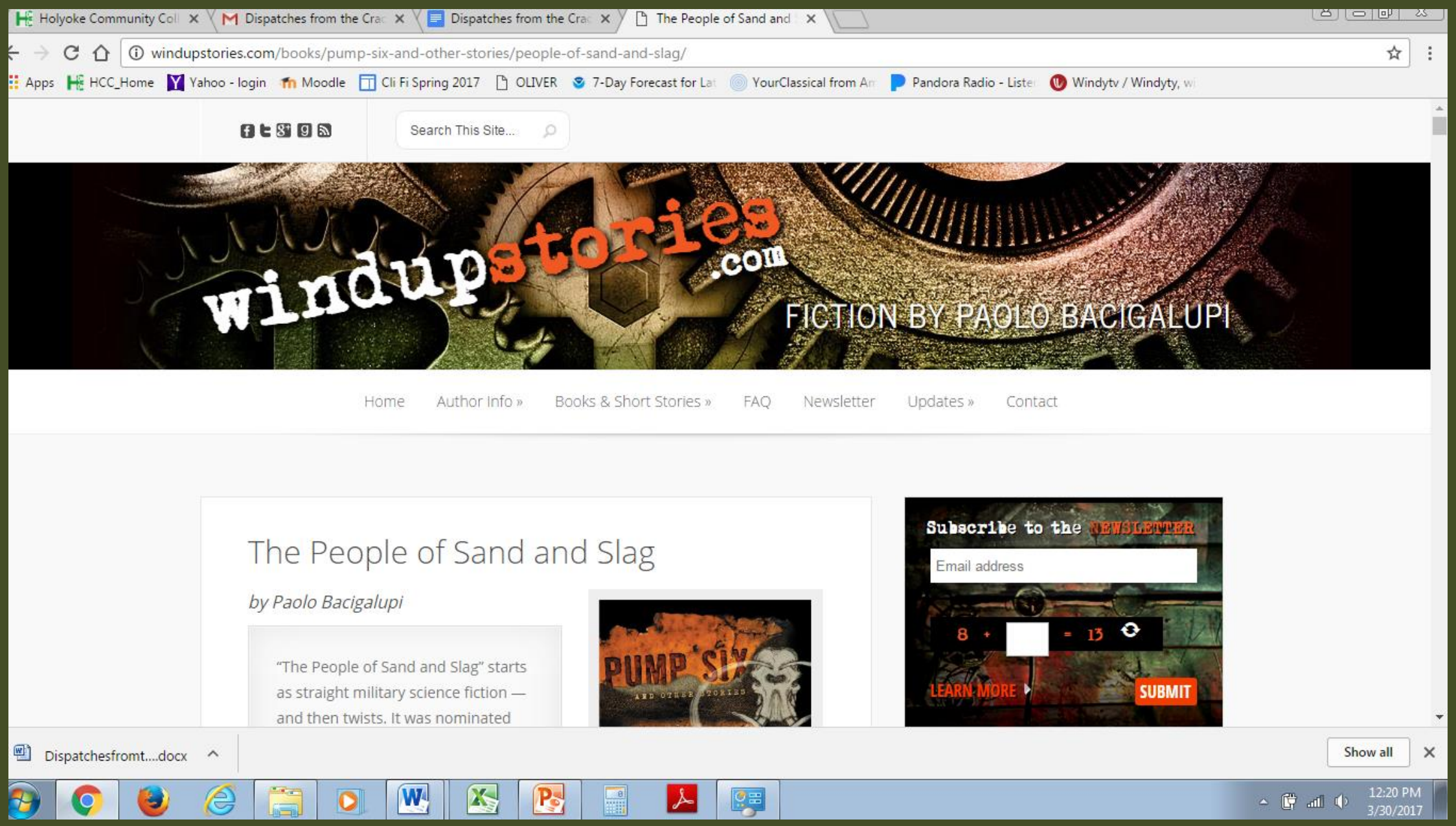




\section{CCSI for “The People of Sand and Slag”}

$\square$ Adaptation/mitigation

$\square$ Breakdown in infrastructure

$\square$ Breakdown in civilization/social order

$\square$ Climate imbalance/disorder

$\square$ Ecosystem imbalance - flora and fauna

$\square$ Illness/disease

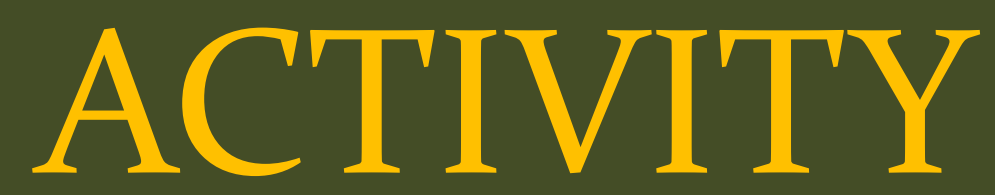

$\square$ Positive/negative feedbacks

$\square$ Regression (psychosocial, biological, technological, etc.)

$\square$ Resource scarcity 


\section{Excerpt 1 from “The People of Sand and Slag” by Paolo Bacigalupi}

We ate sand for dinner. Outside the security bunker, the mining robots tumbled back and forth, ripping deeper into the earth, turning it into a mush of tailings and acid rock that they left in exposed ponds when they hit the water table, or piled into thousand-foot mountains of waste soil. It was comforting to hear those machines cruising back and forth all day. Just you and the bots and the profits, and if nothing got bombed while you were on duty, there was always a nice bonus.

After dinner we sat around and sharpened Lisa's skin, implanting blades along her limbs so that she was a like a razor in all directions $(5)$. 


\section{Excerpt 2 from "The People of Sand and}

Slag”

Lisa laughed and took a spoonful of tailings. "We can eat anything. We're the top of the food chain."

"Weird how it [the dog] can't eat us."

"You've probably got more mercury and lead running through your blood than any pre-weeviltech animal ever could have had."

"That's bad?"

"Used to be poison."

"Weird" (6). 


\section{Intersect example from "The People of Sand and Slag," excerpt 1:}

Text: "We ate sand for dinner."

Example questions:

- How is it possible any living thing could "eat" sand or rock? Have you heard of lichens?

Text: "Outside the security bunker, the mining robots tumbled back and forth, ripping deeper into the earth, turning it into a mush of tailings and acid rock that they left in exposed ponds when they hit the water table or piled into thousand-foot mountains of waste soil.

Example questions:

- Where does the acid come from?

- Can you describe the geochemistry of the tailings ponds?

- How would you describe the "waste soil"? Is it a soil at all? How is the presence of acid related to absence of normal vegetation?

- How are the soils of "The People of Sand and Slag" similar to the soils on the Moon? On Mars? 


\section{Example intersect from "The People of Sand and Slag," excerpt 2:}

Text: "We can eat anything. We're the top of the food chain." Example question:

- But if you can eat anything, aren't you on the bottom of the food chain?

Text: "You've probably got more mercury and lead running through your blood than any pre-weeviltech animal ever could have had."

"That's bad?"

"Used to be poison."

"Weird."

Example questions:

- What's "weeviltech"? (A central concept in Bacigalupi's imagined world. We generally define it as genetically modified organisms or cellular organelles designed to catalyze and metabolize inorganic, otherwise poisonous foodstuffs such as native metals and minerals.)

- What other (real!) organisms may also have adapted weeviltech-like metabolisms?

- In what way do extremophiles have their own version of weeviltech?

- Where on Earth today or in the geologic past have we seen organisms that possess a kind of weeviltech referred to in "The People of Sand and Slag"? 


\section{Cli-Fi Final Short-Story Project}

- "An imaginary garden with real toads in it." - Marianne Moore

- "Cli-fi is where art meets science, where data meets emotions, and where science meets art, too." - Daniel Bloom

Write your own cli-fi short story. Explore any of the ideas, themes, settings, climate/Earth science concepts that have come up in class or in your imagination. While climate change often brings visions of dystopian settings and situations, change can also bring or inspire positive developments. Explore how humans might adapt to a new environment, a new reality. Use real science and the storytelling techniques we have encountered this semester. Integrate at least two climate change impacts (CCSI) into your story. 


\section{Summary}

- Cli-fi engages our sense of wonder. It brings imagination to the problem-solving equation.

- Teaching geoscience with cli-fi starts with a story and moves through the CSSI, showing us how climate change might impact our real-life setting, the Anthropocene.

- Fact-finding/fact-checking the science behind cl-fi engages critical thinking and opens the door to deeper science exploration.

- The Cli-Fi Final Short-Story Project invites students to invent, using climate science knowledge and storytelling techniques learned in class. 


\section{Conclusions, last words}

- Cli-fi illustrates the power of storytelling to offer new perspectives, raise awareness, promote broader thinking, and motivate change.

- Cli-fi helps us teach the science behind climate change.

- Cli-fi reflects our society's concerns about the environment and the planet's future.

- The fictional settings and scenarios of cli-fi enable us to envision our climate-changed future and to confront the role of humanity in climate change.

- The empirical sciences collect data vital to our understanding of the Anthropocene we have created. Storytelling gives meaning to the data and helps us envision human characters struggling to survive in a climate-changed world.

- Some students may be inspired to learn more about the environment and how to preserve and restore it. 


\section{Some cli-fi texts/anthologies}

- Drowned Worlds: Tales from the Anthropocene and Beyond, edited by Jonathan Strahan, Solaris, 2016

- I'm With the Bears: Short Stories from a Damaged Planet, edited by Mark Martin, Verso, 2011

- Loosed Upon the World: the Saga Anthology of Climate Fiction, edited by Joseph Adams, Saga Press, 2015

- "The People of Sand and Slag" by Paolo Bacigalupi (http://windupstories.com/books/pump-six-andother-stories/people-of-sand-and-slag/)

- The Windup Girl, by Paolo Bacigalupi, 2015 Reissue Edition, Night Shade Books 